\title{
THE NATURE OF CARBON FLUX IN GUNUNGSEWU KARST, JAVA-INDONESIA
}

\author{
ZNAČILNOSTI TOKA OGLJIKA V KRAŠKEM OBMOČJU \\ GUNUNG SEWU, JAVA, INDONEZIJA
}

\author{
Eko HARYONO ${ }^{1}$, DANARDONO ${ }^{1}$, Sekti MULATSIH ${ }^{1}$, Sutanto Trijuni PUTRO ${ }^{1} \&$ Tjahyo Nugroho ADJI ${ }^{1}$
}

\begin{abstract}
UDC 551.435.87:547-31/-39(594)

Eko Haryono, Danardono, Sekti Mulatsih, Sutanto Trijuni Putro \& Tjahyo Nugroho Adji: The Nature of Carbon Flux in Gunungsewu Karst, Java-Indonesia

The research documented here aims to clarify the transport and fate of carbon species that evolved in a typical conical karst system in Gunungsewu. Special interest is attributed to the estimate of carbon flux by considering the conical karst as a whole system. It includes carbon input to karst area, soil respiration, SOC, soil $\mathrm{CO}_{2}$, particulate-dissolved and organic carbon, as well as dissolved organic carbon. The research was conducted between 2012 and 2015. Two study sites were selected to represent different morphological and hydrogeological settings. Carbon input was collected for one year round on the basis of conical hill topo-sequence. Carbon input included in this research was litter fall, plant residue, and organic fertilizer. Incorporated with field measurement, soil samples were also collected for SOC estimation. DIC and DOC were estimated from the underground river of Gilap. The results show that carbon flux in the Gunungsewu karst is favored by the agricultural land uses and practices. Accordingly, the organic carbon input to the karst area is governed by spatial distribution of agricultural land uses and practices. Organic carbon input tends to be in the order of organic fertilizer $>$ litter input $>$ and plant residue. Soil $\mathrm{CO}_{2}$ varies in depth and season. Soil organic carbon also varies seasonally, of which the higher content occurs in the rainy season. Most of the carbon is stored as SOC, $20 \%$ is emitted to the atmosphere through soil respiration, and $9 \%$ is transferred to the deeper zone through a hydrological cycle in the form of dissolved organic carbon and particulatedissolved organic carbon. The results suggest that carbon sink in the karst area is ten order higher than that previously estimated from DIC.
\end{abstract}

Key words: soil organic carbon, carbon flux, Gunungsewu, Java, karst carbon sink.

\author{
Izvleček UDK 551.435.87:547-31/-39(594) \\ Eko Haryono, Danardono, Sekti Mulatsih, Sutanto Trijuni \\ Putro \& Tjahyo Nugroho Adji: Značilnosti toka ogljika $v$ \\ kraškem območju Gunung Sewu, Java, Indonezija
}

Namen pričujoče raziskave je pojasniti prenos in usodo ogljikovih spojin, ki so se razvile $\mathrm{v}$ tipičnem stožčastem kraškem sistemu v pokrajini Gunung Sewu. Posebna pozornost je bila namenjena določitvi toka ogljika ob upoštevanju stožčastega krasa kot enotnega sistema. Pri določitvi so bili upoštevani vnos ogljika v kraško območje, SOC, $\mathrm{CO}_{2}$ v prsti, v delcih raztopljeni in organski ter tudi raztopljeni organski ogljik. Raziskava je potekala od leta 2012 do 2015 . Izbrani sta bili dve raziskovalni območji, da bi bilo mogoče zajeti različne morfološke in hidrogeološke značilnosti. Zbiranje podatkov o vnosu ogljika je potekalo skozi vse leto na vznožju stožčastega hriba. V raziskavi so vir vnesenega ogljika predstavljali odpadno listje in stelja, rastlinski ostanki in organsko gnojilo. $\mathrm{V}$ analizo ocene SOC so bili v okviru terenskih meritev vključeni tudi zbrani vzorci prsti. DIC in DOC sta bila določena na podlagi vzorcev iz podzemne reke Gilap. Rezultati so pokazali, da je tok ogljika v kraškem območju Gunung Sewu pretežno posledica kmetijske dejavnosti. Temu primerno je vnos organskega ogljika v kraško območje rezultat prostorske porazdelitve kmetijske dejavnosti in njene intenzivnosti. Vnos organskega ogljika je glede na delež sledeč: organsko gnojilo > odpadno listje in stelja > rastlinski ostanki. Vsebnost $\mathrm{CO}_{2} \mathrm{v}$ prsti je glede na globino in letni čas različna. Glede na letni čas se spreminja tudi vsebnost organskega ogljika v prsti, saj ga je največ v deževnem obdobju. Večina ogljika je skladiščenega v obliki SOC, 20 \% se ga zaradi dihanja tal sprosti v ozračje, $9 \%$ pa je ob kroženju vode v obliki raztopljenega organskega ogljika in v delcih raztopljenega organskega ogljika prenesenega globlje v tla. Rezultati kažejo, da je ponor ogljika $\mathrm{v}$ kraško območje $\mathrm{v}$ primerjavi s preteklimi ocenami, pridobljenimi iz DIC, desetkrat višji.

Ključne besede: organski ogljik v prsti, tok ogljika, Gunung Sewu, Java, ponor ogljika v kras.

\footnotetext{
${ }^{1}$ Karst Research Group, Faculty of Geography. Universitas Gadjah Mada, Yogyakarta, INDONESIA e-mail: e.haryono@ugm.ac.id, danardono91@gmail.com, smulatsih@gmail.com, sutanto0612@gmail.com; adji@geo.ugm.ac.id Received/Prejeto: 10.04.2016
} 


\section{INTRODUCTION}

The important of karst area in the carbon cycle has drawn scientific inquiries since the late $20^{\text {th }}$ century. Its importance is not only because the karst system develops in carbon-binding rocks (carbonate rocks) but also because of its unique role in the biogeochemical carbon cycle. Carbonate rocks are the largest inorganic carbon reservoir in the near surface of planet Earth (Berner et al. 1983; Mackenzie 2004). Though karst process takes place in terrestrial environments, its occurrence cannot be separated from the entire carbonate sediment and biogeochemical carbon cycle. In terrestrial environments, the karst system plays various roles in the carbon cycle through karst processes, especially weathering of carbonate rock, where the process uptakes $\mathrm{CO}_{2}$ (Haryono 2013; Huang et al. 2015; Liu et al. 2010; Liu \& Zhao 2000; White 2013; Yuan 1997).

Atmospheric $\mathrm{CO}_{2}$ sink as dissolved organic carbon (DIC) resulting from carbonate dissolution constitutes up to $29.4 \%$ of the terrestrial $\mathrm{CO}_{2}$ sink or $10.4 \%$ of total anthropogenic $\mathrm{CO}_{2}$ emission. The estimate was based on theoretical calculation and field monitoring evidence (Liu et al. 2010). The nature of the carbon cycle in a karst system is comparably dynamic, subject to spatial and temporal variability. Empirical data from China, Spain, Yugoslavia, France, and other places were made comparable during the 1995 to 1999 IGCP378 project (Yuan \& Zang 2002). The data unveiled that the karst process has a unique carbon cycle mechanism. The process is controlled by interplay between hydrosphere, lithosphere, atmosphere, and biosphere through a dissolution process in the near surface zone. Sensitivity of the carbon cycle in karst systems is not only seasonal, but also could be daily, hourly, or less (Adji et al. 2016; Adji 2012; de Montety et al. 2011; Jiang et al. 2013; Liu et al. 2007).

Aside from cycling as dissolved inorganic carbon, carbon also cycles through organic matter and dissolved organic carbon (DOC). White (2013) suggested that most of the carbon flux in karst is governed by vegetation carbon cycle. Input carbon from vegetation litter is stored in the soil, of which some portion is transferred to the deeper zone through percolating water and sinking streams as dissolved organic carbon and particulate organic carbon (Simon et al. 2007). As with inorganic carbon, organic carbon is also comparably complex and dynamic. The complexity starts with the variability of organic carbon input, especially vegetation litter either in different time scales or in spatial scales. The complexity of the carbon cycle in the form of organic carbon is also governed by temporal variability of climate, especially temperature and rainfall.

Complexity of organic carbon must have taken place in Gunungsewu karst where the area has a unique setting in terms of morphology, climatology, and land use condition. Cockpit karst morphology with monsoonal climate, as well as land use pattern with different agricultural practices is likely to result in the unique behavior of carbon flux. This paper is an effort to understand the nature of the carbon cycle in typical cockpit karst of Gunungsewu, in order to provide comparable knowledge about the global understanding of the carbon cycle in karst and the important of karst in carbon sink. The discussion will deal with the variability of input carbon, carbon sink, and its flux.

\section{THE STUDY AREA}

Two study sites within Gunungsewu karst were selected, namely the recharge area of Ngeleng Spring and recharge area of the Gilap subterranean river. Ngeleng is an epikarst spring characterized by diffuse-fissure flow (Adji et al. 2016; Adji \& Bahtiar 2016). On the other hand, the Gilap subterranean river is a large recharge area with a conduit flow characteristic (Fig. 1). The recharge area of the Gilap subterranean river and Ngeleng Spring consecutively are 3,350 ha and 30.4 ha.

The two study sites are situated in cockpit karst of Gunungsewu (Haryono \& Day 2004; Haryono 2000) with a typical karstic hydrogeological system characterized by conduit, fissure, and diffuse compo- nents. Fissure and diffuse flow is the most important recharge component during the dry season, whereas quick infiltration of the surface water is a dominant recharge component during the rainy season (Eiche et al. 2016). The Gunungsewu karst is situated in the island arc of convergence margin between the HindiaAustralia Plate and the Southeast Asia fragment of the Eurasian Plate. This tectonic setting is the major control of the geological setting of the area. The host rock of the Gunungsewu karst is made up of Neogen (Middle Miocene and Upper Pliocene) of Wonosari Formation. The limestone is composed of massive coralline limestone and bedded chalky limestone 


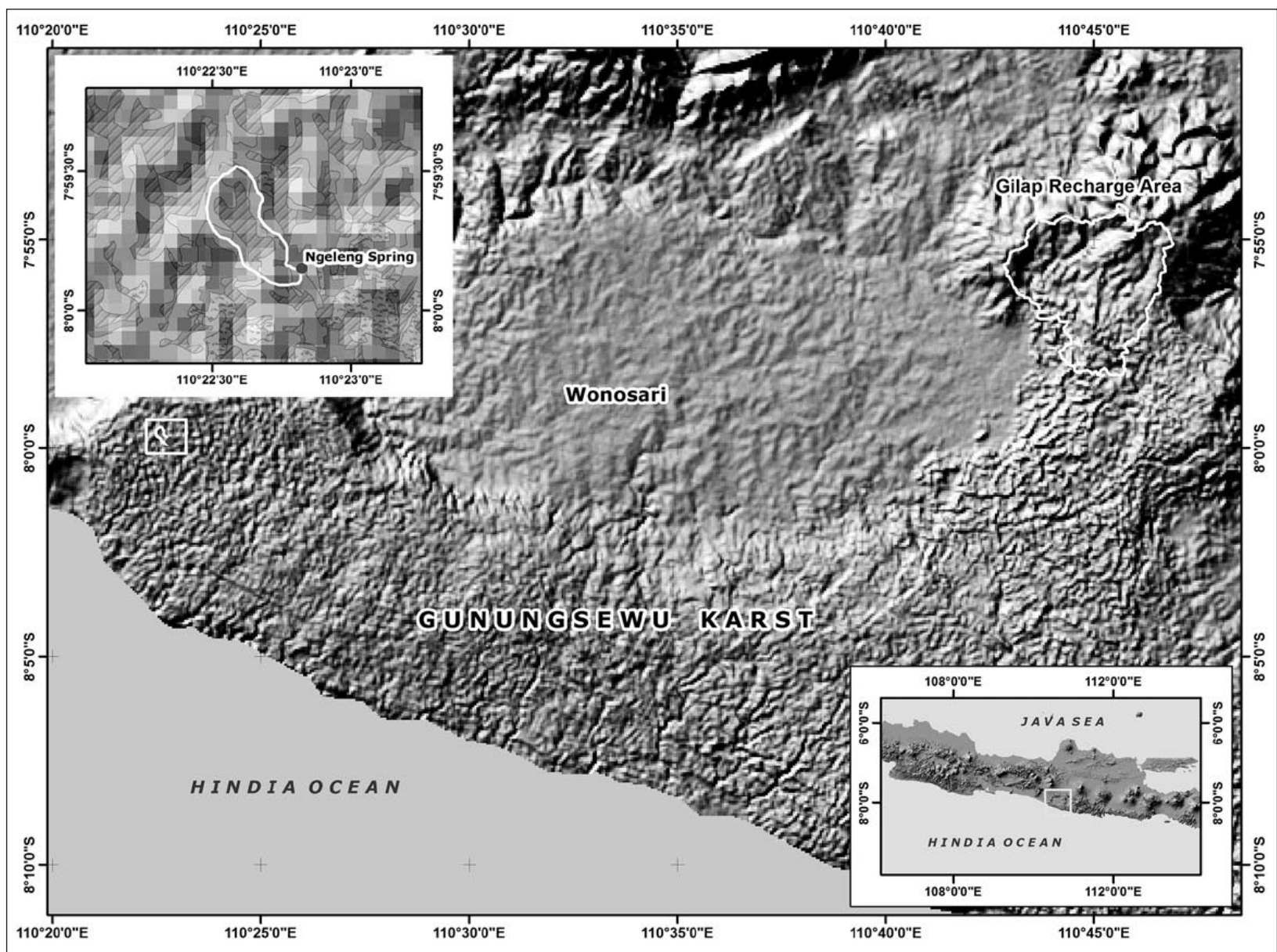

Fig. 1: The study areas. Ngeleng recharge area is situated in the left picture drawn in a white line, and the Gilap subterranean recharge area is in the right picture depicted in the white line.

(Balazs 1968; Bemmelen 1970; Rahadjo et al. 1995; Surono et al. 1992; Waltham et al. 1983). Total thickness of the limestone exceeds $650 \mathrm{~m}$. The lithology of coralline limestone is highly variable, but the area was dominated by rudstones, packstones, and framestones. Bioherm structures are identifiable, and lenses of volcanic ash are interspersed among the carbonates (Waltham et al. 1983).

The Wonosari Formation has been uplifted since the late Pliocene and/or early Pleistocene Epoch. The limestone bed is dipping gently southward at about a $2 \%$ gradient, and marked by a high cliff $(25-100 \mathrm{~m})$ along the south coast (Balazs 1968; Bemmelen 1970; Surono et al. 1992; Sutoyo 2005). North-south compression associated with tectonic plate convergence produced deformation, including intensive northwest-southeast and northeast-southwest jointing and faulting (Haryono \& Day 2004; Surono et al. 1992; Sutoyo 2005). The structure is most complex along the northern boundary.

The prevailing contemporary climate in the $\mathrm{Gu}-$ nungsewu karst is strongly influenced by monsoons, which produce a distinct wet season from October to April and a dry season between May and September. The annual rainfall, recorded from 14 local rain gauge stations in the area during 1960 and 1997 varies between $1500 \mathrm{~mm}$ and $2986 \mathrm{~mm} /$ year. Mean annual temperature is about $27{ }^{\circ} \mathrm{C}$ (Haryono \& Day 2004). This climate pattern governs the agricultural land uses in the area. In the rainy season, the area looks green because of vegetation coverage but turns to a brownish color of bare land in the dry season (Fig. 2). The area is dominated by dry land cultivation and mixed garden. Seasonal dry land cultivation of multiple cropping is grown in the bottom of the cockpit and lower slope of conical karst hills. Multiple cropping in the area constitutes maize, cassava and rain-fed rice or groundnuts (Haryono 2011). Mixed perennial crops are practiced in sloping part of conical hills and upper slope. In some localities, conical karst hills are left as bare land. Mixed perennial crops are dominated by teak (Tectona grandis) and acacia (Acacia mangium). 

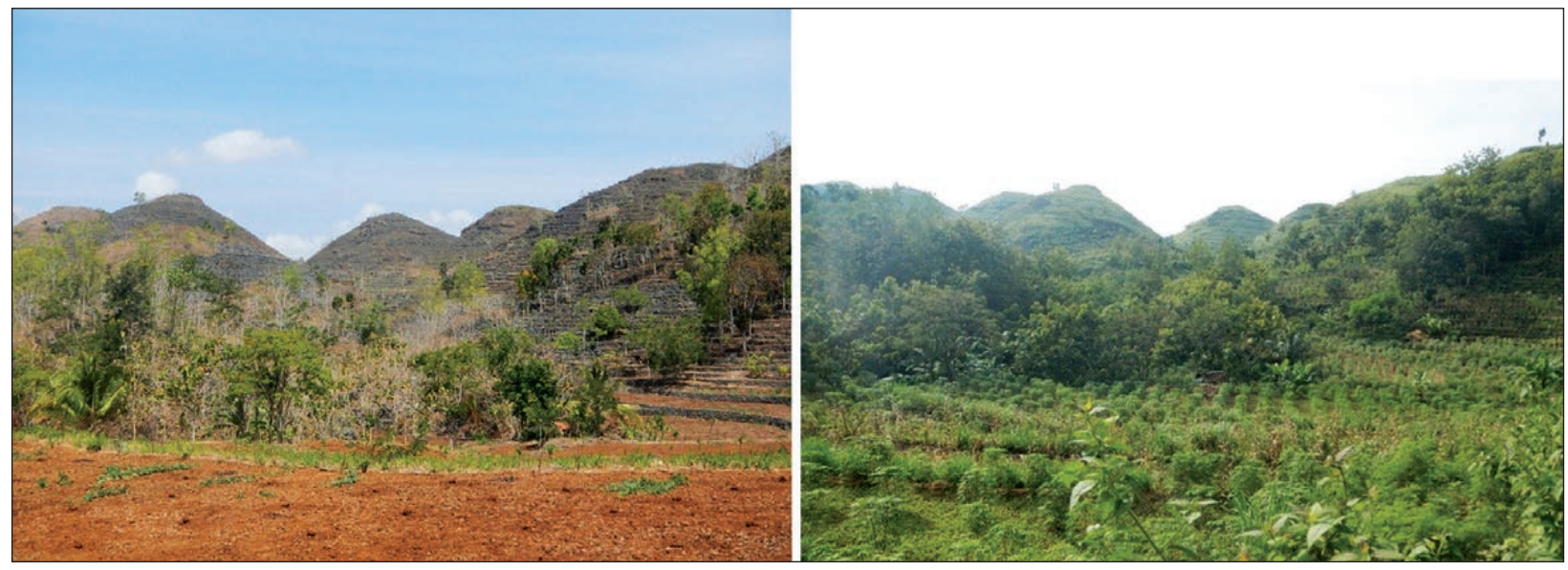

Fig. 2: Situation of agricultural land uses in dry and rainy seasons. In the photograph, conical karst is left as bare land, however most of the upper slope is planted with mixed perennial crops. The bottom of the cockpit is used for seasonal crops (Photo: Sutanto Trijuni Putro).

\section{METHODS}

This research employed different methodologies related to carbon input, soil respiration, soil $\mathrm{CO}_{2}$, soil organic carbon (SOC), dissolved inorganic carbon, dissolved and particulate organic carbon, as well as carbon redistribution within karst systems. Inputs of carbon include $\mathrm{CO}_{2}$ air, litter fall, plant residue, and organic fertilizer. Measurement of input carbon and respiration were conducted in the crest, slope, and bottom of conical hills. Whereas, soil $\mathrm{CO}_{2}$ and air $\mathrm{CO}_{2}$ were conducted in two different land uses, i.e. in mixed perennial crops and in seasonal cropland.

Litter fall was weighted from an area of $4 \mathrm{~m}^{2}$ for one year round after the ground surface was cleaned up. Dry litter (biomass) was then converted to carbon equivalent. Respiration was measured using the static closed chamber method. Plant residue was weighted after harvesting time. Organic fertilizer was estimated from the data derived from interviews with local farmers and then converted to $\mathrm{C}$ equivalent. Air $\mathrm{CO}_{2}$ data was collected by a Telair $7001 \mathrm{CO}_{2}$ sensor. $\mathrm{CO}_{2}$ soil was measured using a Kitagawa gas detector tube in three different depths (20, 40 , and $60 \mathrm{~cm}$ ). $\mathrm{CO}_{2}$ measurement was also conducted in the regolith at a depth of $65 \mathrm{~cm}$. Incorporation with above measurements, soil and land characteristics were observed, i.e. slope, outcrop, permeability, soil type, soil depth, and $\mathrm{pH}$. Soil samples were collected for SOC, soil density, and texture analyses in the laboratory. Soil organic carbon was analyzed using the Walkey and Black Method (Walkey \& Black 1934).

Carbon redistribution in this research includes redistribution by soil erosion and hydrological cycles. Erosion rate data was collected through the erosion pin method for one year round. Carbon redistribution through a hydrological cycle was conducted by monthly monitoring of $\mathrm{HCO}_{3}^{-}$and major ion. Major ion was used for $\mathrm{CO}_{2}$ partial pressure calculation. $\mathrm{HCO}_{3}^{-}$was titrated in the field using alkalinity test kits. Dissolved and particulate organic carbon was collected every two weeks. Organic samples were collected from the underground river and drip water of the Gilap subterranean river. Water samples were collected using the IAEA method and analyzed using the Walkey and Black Method. Discharge monitoring was conducted using the Hobo water level and electric conductivity logger.

Carbon flux was estimated from percentage of carbon equivalence in different carbon occurrences to the total organic carbon input. To make it comparable, carbon is converted in annual time scale and in one hectare area (tons/ha/y). Inorganic carbon input from atmosphere was excluded in the estimate. 


\section{RESULTS}

\section{INPUTS OF CARBON}

Inputs of carbon to the karst area of Gunungsewu come from air $\mathrm{CO}_{2}$, biomass (litter and plant residue), and from organic fertilizer. Litter and plant residues in the area are mostly from mixed perennial crops and seasonal crops. Those two land uses are the dominant crops and the major biomass input to the karst area of Gunungsewu karst. Seasonal crops grown in the Gunungsewu karst are rainfed paddy (Oryza sativa), cassava (Manihot utilissima), corn (Zea mays) or peanuts (Arachis hypogaea). Perennial crops grown in the area are teak (Tectona grandis), acacia (Acacia mangium), and shrubs. Different kinds of timber plantation and fruit crop in lesser percentages are also present. Mixed perennial crops in the Gunungsewu karst are planted in the crest of conical hills, whereas seasonal crops are planted in in the slope of conical and foot slope/bottom of cockpit. The general condition of land uses and soil properties of the Gunungsewu karst, where measurements were conducted, is presented in Fig. 3.

Measurement of air/atmosphere $\mathrm{CO}_{2}$ during midday from different land uses in Gunungsewu karst area is presented in Tab. 1. The highest $\mathrm{CO}_{2}$ concentration was found in the settlement area and the lowest concentration was measured in mixed perennial crops. The $\mathrm{CO}_{2}$ air in Gunungsewu karst is in the range generally found in the global atmosphere.
Measurement of organic carbon input from 10 conical karst hills topo-sequence is presented in Tab. 2. Organic carbon input in the Gunungsewu karst spatially varies within topo-sequence where the highest leave litter input is found in the crest. Besides litter and crop residue, input of organic carbon in Gunungsewu karst is derived from organic fertilizer. The highest input of organic fertilizer takes place in the bottom of the cockpit. High input of organic carbon from fertilizer in the bottom of the cockpit should be explained by the fact that this area has the most potential land for agricultural land

Tab. 1: Air $\mathrm{CO}_{2}$ of different land uses in Gunungsewu karst area.

\begin{tabular}{l|l|c}
\hline No & Land Uses & $\mathrm{CO}_{2}(\mathrm{ppm})$ \\
\hline 1. & Settlement & 416 \\
\hline 2. & Mixed perennial crops & 232 \\
\hline 3. & Mixed perennial crops & 202 \\
\hline 4. & Dry land seasonal crops & 386 \\
\hline 5. & Mixed garden & 335 \\
\hline 6. & Rain-fed paddy & 398 \\
\hline 7. & Mixed garden & 342 \\
\hline 8. & Dry land seasonal crops & 388 \\
\hline 9. & Rain-fed paddy & 390 \\
\hline 10. & Mixed garden & 352 \\
\hline & Average & 344 \\
\hline
\end{tabular}

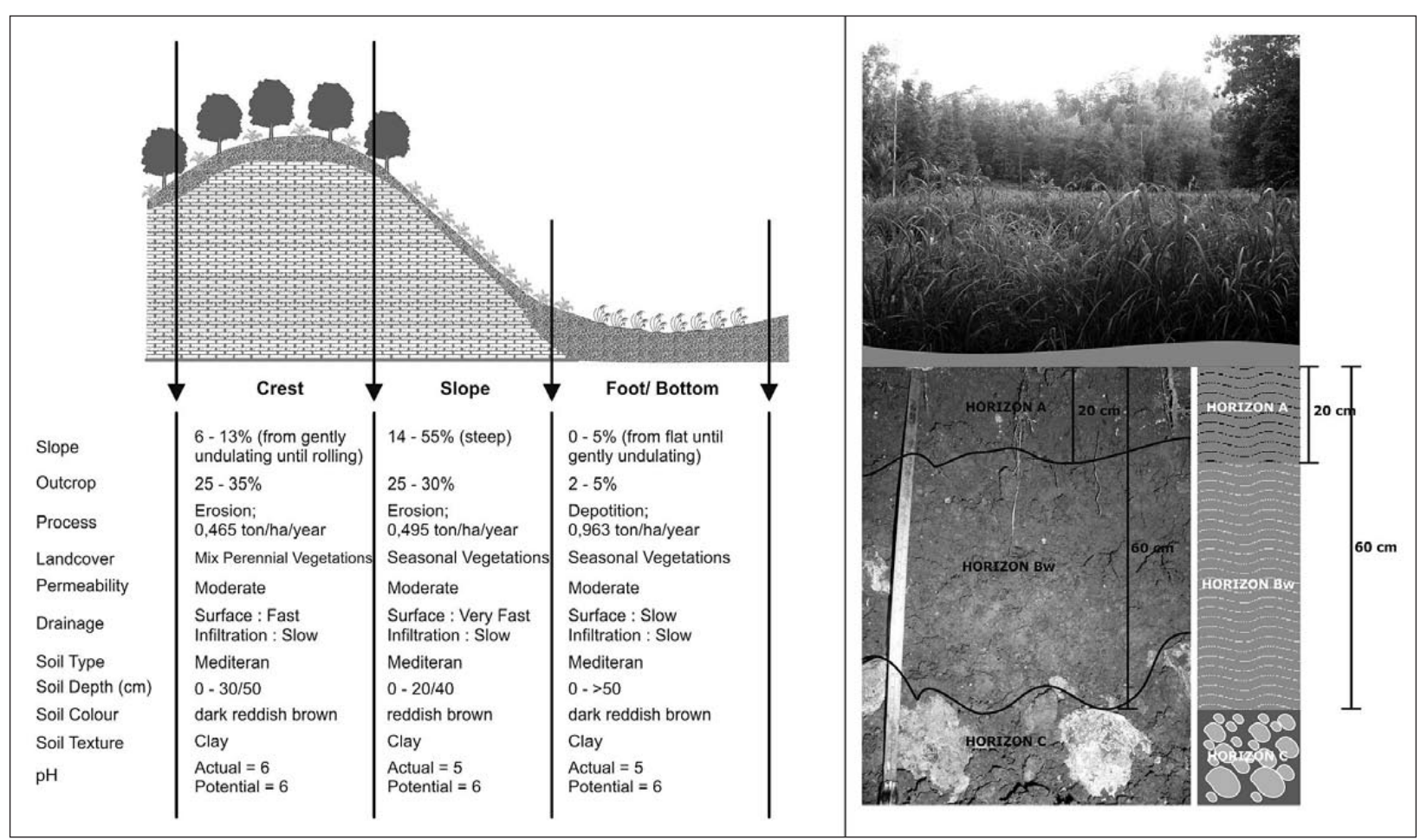

Fig. 3: Characteristics of conical karst hill topo-sequence and typical soil profile in Gunungsewu karst. 
Tab. 2: Organic Carbon Input in Gunungsewu karst (in tons C/ha/year).

\begin{tabular}{|c|c|c|c|c|c|c|c|c|c|}
\hline \multirow{2}{*}{$\begin{array}{l}\text { Sample } \\
\text { Sites }\end{array}$} & \multicolumn{3}{|c|}{ Crest } & \multicolumn{3}{|c|}{ Slope } & \multicolumn{3}{|c|}{$\begin{array}{c}\text { Foot / } \\
\text { Bottom of Cockpit }\end{array}$} \\
\hline & $\begin{array}{l}\text { Plant } \\
\text { litter }\end{array}$ & $\begin{array}{l}\text { Plant } \\
\text { residue }\end{array}$ & $\begin{array}{l}\text { Organic } \\
\text { fertilizer }\end{array}$ & $\begin{array}{l}\text { Plant } \\
\text { litter }\end{array}$ & $\begin{array}{l}\text { Plant } \\
\text { residue }\end{array}$ & $\begin{array}{l}\text { Organic } \\
\text { fertilizer }\end{array}$ & $\begin{array}{l}\text { Plant } \\
\text { litter }\end{array}$ & $\begin{array}{l}\text { Plant } \\
\text { residue }\end{array}$ & $\begin{array}{l}\text { Organic } \\
\text { fertilizer }\end{array}$ \\
\hline $\mathrm{T} 1$ & 5.353 & 0.300 & 4.197 & 6.114 & 0.162 & 6.044 & 0.000 & 4.017 & 10.852 \\
\hline $\mathrm{T} 2$ & 3.346 & 2.769 & 8.058 & 3.650 & 0.496 & 10.073 & 0.000 & 1.491 & 12.631 \\
\hline T3 & 2.373 & 4.177 & 8.058 & 2.981 & 0.571 & 18.131 & 0.000 & 0.571 & 2.686 \\
\hline T4 & 24.333 & 4.054 & 6.715 & 3.042 & 0.150 & 4.835 & 0.000 & 2.495 & 2.015 \\
\hline T5 & 85.167 & 0.000 & 0.000 & 2.738 & 0.150 & 8.058 & 0.000 & 2.884 & 9.411 \\
\hline T6 & 24.333 & 2.885 & 5.036 & 1.460 & 0.000 & 0.000 & 0.000 & 4.223 & 8.058 \\
\hline $\mathrm{T} 7$ & 15.817 & 0.000 & 0.000 & 15.817 & 3.808 & 11.416 & 0.000 & 2.468 & 6.715 \\
\hline T8 & 4.821 & 0.000 & 0.000 & 0.000 & 17.831 & 16.116 & 0.000 & 21.914 & 20.145 \\
\hline T9 & 8.838 & 0.000 & 0.000 & 0.000 & 18.627 & 16.116 & 0.000 & 17.716 & 16.116 \\
\hline T10 & 3.483 & 0.000 & 0.000 & 0.084 & 6.248 & 6.044 & 0.000 & 8.898 & 8.058 \\
\hline Average & 17.786 & 1.419 & 3.206 & 3.588 & 4.804 & 9.683 & 0.000 & 6.668 & 9.669 \\
\hline
\end{tabular}

Note: Samples T8, T9, T10 from Mulatsih et al. (2011).

use. Organic fertilizer is not only applied to seasonal crops, but also applied to mixed perennial crops. Therefore, carbon organic input from organic fertilizer is considerably significant in Gunungsewu karst.

\section{SOIL ORGANIC CARBON (SOC) AND SOIL $\mathrm{CO}_{2}$}

Organic carbon is stored in the soil as soil organic carbon (SOC). A portion of it is decomposed by microorganisms, resulting in soil $\mathrm{CO}_{2}$ gas. Soil $\mathrm{CO}_{2}$ gas is then emitted to the atmosphere and some of it remains in the soil. $\mathrm{SOC}$ and soil $\mathrm{CO}_{2}$ in Gunungsewu karst varies considerably, either in spatial or temporal terms. Spatially, SOC is governed by land uses and topographic position. Different soil organic carbon (SOC) from different land uses and topographic position is presented in Fig. 4. In general, seasonal cropland has lower SOC than that of mixed perennial cropland. Lower SOC in the seasonal cropland should be explained by the lower input of biomass to the soil, compared to that in the mixed perennial crop soil. Less biomass in the seasonal cropland is returned back to the soils. The greatest percentage of biomass is brought out from the land for cattle feeding or other purposes. Seasonal cropland is left bare during dry seasons, when not even grass is able to grow.

With respect to topographical position, higher SOC percentage is found in the crest of conical karst hills of which the land used is mixed perennial crops. Perennial crops grown in the area are teak (Tectona grandis) plantation, acacia (Acacia mangium), and shrubs. Normally, teak is cut down every 15 years or more, whereas acacia is harvested every 5 years for fuel wood. The lowest SOC content is found in the foot of conical hills or the bottom of the cockpit. However, in terms of bulk volume, the bottom of the cockpit is the place where the SOC is mostly stored. High storage capacity at the bottom of cockpit in Gunungsewu karst is a result of the thicker soils and higher bulk soil volume in the bottom of cockpits.

With respect to vertical distribution, SOC in the Gunungsewu karst unveils an increment pattern to the depth. The lowest SOC content is found in the topsoil and increases significantly to a depth of $60 \mathrm{~cm}$. From this depth, SOC becomes lower to the interface of soils and underlying rock. The same pattern is also found in the vertical distribution of soil $\mathrm{CO}_{2}$. The highest soil $\mathrm{CO}_{2}$ is found at a depth of $60 \mathrm{~cm}$ and decreases at the interface of soil and underlying limestone. The lower SOC and soil $\mathrm{CO}_{2}$ in the shallow soil depth is likely a result of the soil $\mathrm{CO}_{2}$ release to the atmosphere through soil respiration. On the other hand, lower soil $\mathrm{CO}_{2}$ in the soil-limestone interface presumably is consumed by dissolution processes of the underlying limestone. SOC also varies within annual seasonal cycles. In general, SOC and soil $\mathrm{CO}_{2}$ is higher in the rainy season. Rainfall not only provides water for crops, but also transfers SOC surface to soil profile through percolating water.

\section{CARBON REDISTRIBUTION}

As mentioned earlier, stored carbon in karst soil is in turn emitted to the atmosphere through soil respiration as an inorganic carbon and transported to the deeper karst system by percolating water. Carbon is transported through percolating water in the form of particulate, dissolved organic carbon, as well as inorganic carbon. Small other portions are redistributed by erosion from the crest to the lower slope and at the bottom of the cockpit. Soil respiration mostly emits soil $\mathrm{CO}_{2}$ at the near surface. Soil respiration in Gunungsewu karst is presented in Tab. 3. It shows that soil respiration varies spatially, depending upon land uses and topographical position. High soil respiration takes place in the crest of conical karst hills, of 


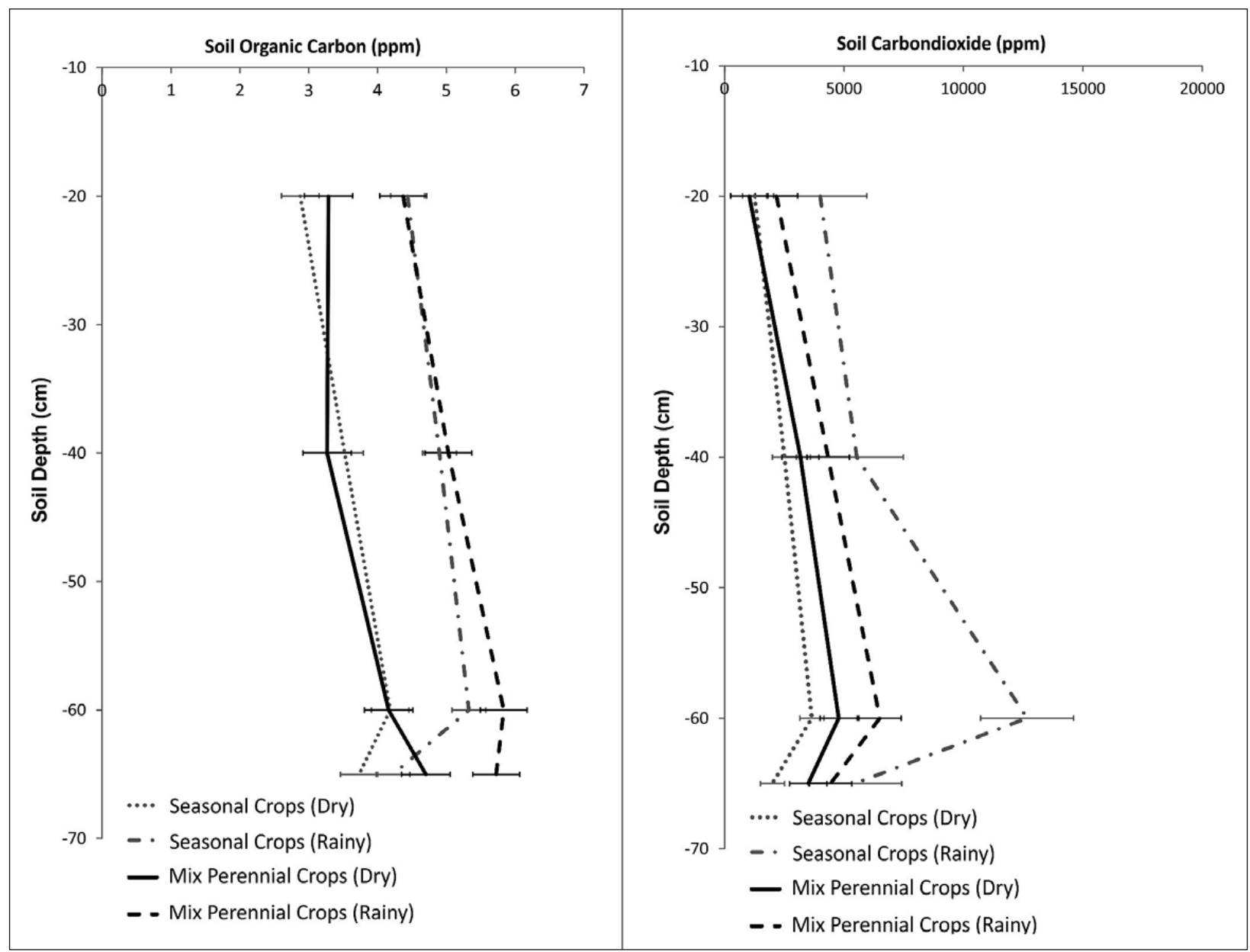

Fig. 4: Vertical and seasonal variation of SOC and soil CO2 in two different land uses and seasons.

Tab. 3: Soil respiration in conical karst of Gunungsewu karst (in tons $\mathrm{C} / \mathrm{ha}$ /year).

\begin{tabular}{l|l|l|l}
\hline Samples & Crest & Slope & Foot \\
\hline T1 & 1.656 & 0.366 & 1.105 \\
\hline T2 & 3.500 & 1.767 & 3.329 \\
\hline T3 & 5.226 & 1.662 & 2.003 \\
\hline T4 & 9.693 & 1.775 & 1.505 \\
\hline T5 & 1.861 & 1.964 & 0.507 \\
\hline T6 & 4.421 & 7.991 & 1.346 \\
\hline T7 & 5.581 & 7.502 & 2.438 \\
\hline Average & 4.563 & $\mathbf{3 . 2 8 9}$ & $\mathbf{1 . 7 4 7}$ \\
\hline
\end{tabular}

which the major land use is mixed perennial crops. The lowest soil respiration occurs in the foot/bottom of the cockpit where the land use is seasonal crops. This distribution pattern coincides with the SOC distribution described previously, to which the high respiration takes place at soils with high SOC content.

In addition to being emitted to the atmosphere, soil $\mathrm{CO}_{2}$ is consumed by karst processes in the epikarst zone.
Carbon is then transported by water cycle to the underground river and springs as bicarbonate ion. Bicarbonate ion detected in the underground river of Gilap and Ngeleng Spring is presented in Tab. 4. The table shows that the major temporal variation of inorganic carbon in the karst water is driven by the monsoonal annual cycle, of which the high level is in the dry season and low concentration occurs in the rainy season. However, the different magnitude of the $\mathrm{HCO}_{3}^{-}$concentration between rainy and dry seasons is variable depending on karst aquifer characteristics. Slight variability of $\mathrm{HCO}_{3}^{-}$concentration between dry and wet seasons is found in Ngeleng Spring, where the aquifer is dominated by diffuse and fissure flow. On the other hand, high magnitude variability is found in the Gilap underground river where conduit flow has already developed well and is partly recharged by the allogenic river. The highest $\mathrm{HCO}_{3}^{-}$concentration in the rainy season is 2.5 degrees higher than that in dry season.

Apart from inorganic carbon, carbon is also transported through hydrological cycles as an organic carbon. 
Tab. 4: Monthly average bicarbonate concentration and $\mathrm{PCO}_{2}$ in water.

\begin{tabular}{l|c|c|c|c}
\hline \multirow{2}{*}{ Month } & \multicolumn{2}{|c|}{ Gilap } & \multicolumn{2}{c}{ Ngeleng } \\
\cline { 2 - 5 } & $\mathrm{HCO}_{3}^{-}(\mathrm{ppm})$ & Log PCO & $\mathrm{HCO}_{3}^{-}(\mathrm{ppm})$ & Log PCO \\
\hline November & 265.0 & -1.950 & & -1.753 \\
\hline December & 145.0 & -1.750 & 398.6 & -1.239 \\
\hline January & 122.0 & -1.470 & 357.9 & -1.375 \\
\hline February & 110.0 & -1.880 & 339.8 & -1.440 \\
\hline March & 131.0 & -1.710 & 375.2 & -1.593 \\
\hline April & 154.0 & -1.758 & 372.2 & -1.293 \\
\hline May & 217.0 & -1.896 & 374.2 & -1.301 \\
\hline June & 223.7 & -2.041 & 384.4 & -1.495 \\
\hline July & 228.2 & -2.904 & 384.4 & \\
\hline August & 232.0 & -2.916 & & \\
\hline September & 242.2 & -3.089 & & \\
\hline Average & & & & \\
\hline
\end{tabular}

Tab. 5: Organic Carbon in the Gilap underground river (in $m g / l$ ).

\begin{tabular}{l|c|c|c|c}
\hline Date & $\begin{array}{c}\text { Rainfall } \\
(\mathbf{m m})\end{array}$ & $\begin{array}{c}\text { Sinking } \\
\text { stream }\end{array}$ & $\begin{array}{c}\text { Gilap } \\
\text { Stream }\end{array}$ & $\begin{array}{c}\text { Drip } \\
\text { Water }\end{array}$ \\
\hline 18-May & 0.20 & 5,713 & 4,277 & 2,074 \\
\hline 28-May & 0.00 & 2,852 & 3,353 & 4,925 \\
\hline 30-May & 0.00 & 2,203 & 4,666 & 2,192 \\
\hline 1-Jun & 0.00 & 2,192 & 2,321 & 2,851 \\
\hline 6-Jun & 1.80 & 774 & 1,418 & 3,224 \\
\hline 8-Jun & 0.00 & 1,296 & 4,277 & 1,426 \\
\hline 12-Jun & 0.00 & 903 & 3,353 & 5,055 \\
\hline 14-Jun & 0.00 & 2,074 & 2,203 & 1,296 \\
\hline 16-Jun & 0.00 & 2,321 & 1,934 & 1,167 \\
\hline Average & & $\mathbf{2 , 2 5 9}$ & $\mathbf{3 , 0 8 9}$ & $\mathbf{2 , 6 9 0}$ \\
\hline
\end{tabular}

Organic carbon is brought to the underground river either through percolating water or from sinkholes. There was not enough data to infer whether organic carbon fluctuated over the seasonal cycle. Data was only available during the dry season, as presented in Tab. 5. The data shows that SOC in Gunungsewu karst is partly brought to the deeper zone by water. The amount of
Tab. 6: Carbon redistribution by soil erosion.

\begin{tabular}{l|c|c}
\hline $\begin{array}{l}\text { Topographic } \\
\text { Position }\end{array}$ & $\begin{array}{c}\text { Erosion } \\
\text { (Tons/ha/y) }\end{array}$ & $\begin{array}{c}\text { Transported C } \\
\text { (Tons/Ha/y) }\end{array}$ \\
\hline Crests & 0.465 & 0.025 \\
\hline Slope & 0.498 & 0.016 \\
\hline Foot slope & 0.963 & 0.035 \\
\hline Average & $\mathbf{0 . 6 4 2}$ & $\mathbf{0 . 0 2 5}$ \\
\hline
\end{tabular}

sinking organic carbon in the karst area is approximately 0.56 tons/ha/year.

SOC is also redistributed by erosion from the crest to the lower slope and bottom of the cockpit. This process mostly involves SOC in the soil surface and topsoil. Erosion in the area is accelerated due to conversion of forest to agricultural land. To reduce the erosion rate, local farmers construct terraces made from limestone boulder pile. The basic idea of constructing terrace in the area is to trap soil in a bid of extending arable land; thus this measure is also effective for erosion control. The average erosion rate in the area is presented in Tab. 6.

\section{DISCUSSION}

Carbon flux in the Gunungsewu karst exhibits general behavior as suggested by previous works from different localities. However, Gunungsewu karst has a unique nature of carbon flux with respect to input, transfer, and storage. The nature of carbon flux in Gunungsewu karst is presented in Fig. 5. The major source of carbon in $\mathrm{Gu}$ nungsewu karst is favored by the agricultural land uses and practices. Accordingly, the organic carbon input is governed by spatial distribution of agricultural land uses and practices. Interestingly, the result shows that the contribution of organic fertilizer (manure) is slightly higher than that from crop biomass, especially in the seasonal cropland. Although application of manure has been reported as a carbon sink, the application of manure in the Gunungsewu area is significantly much higher than that reported from different areas by previous work (Shrestha 


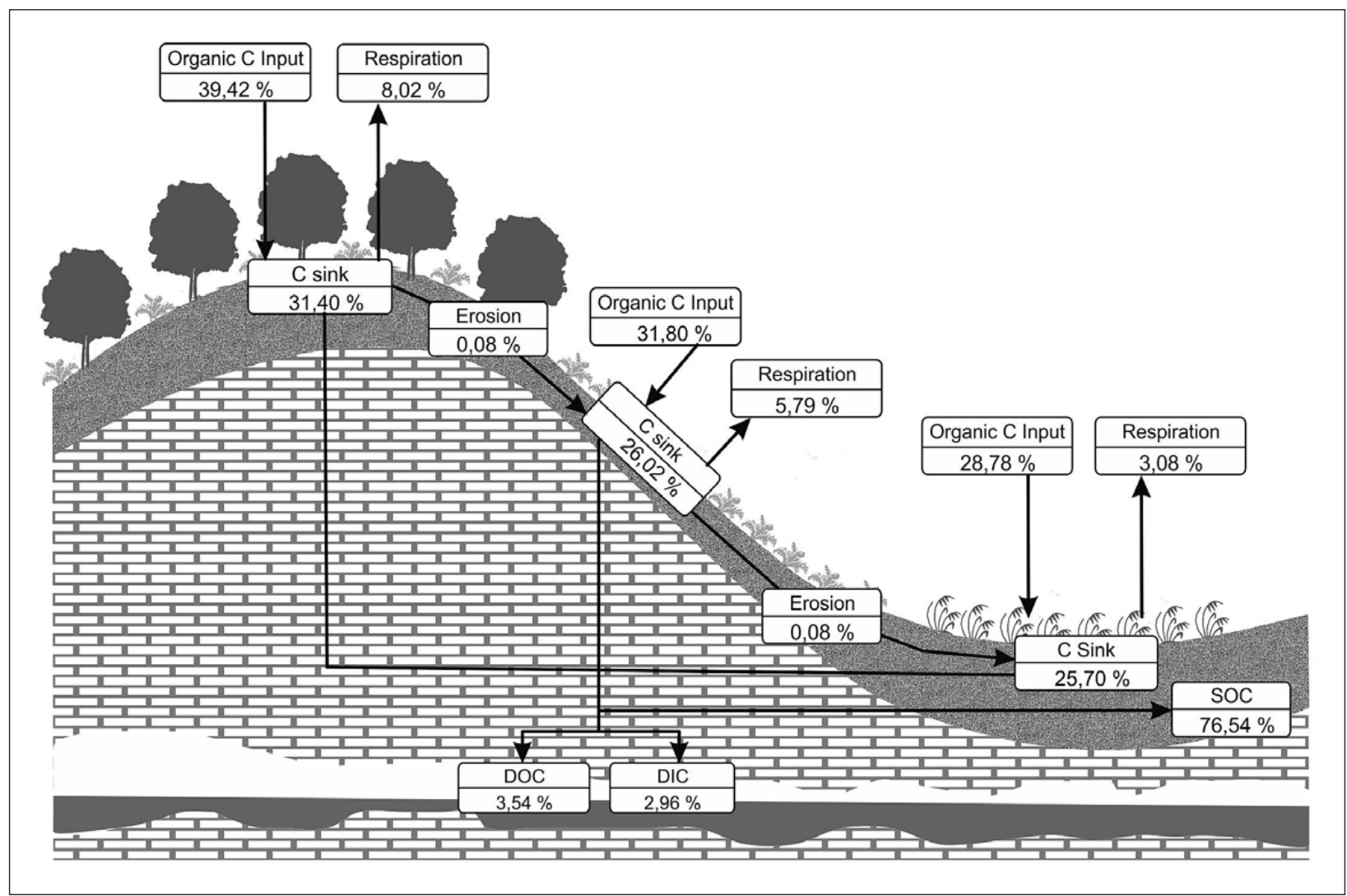

Fig. 5: Carbon flux in Gunungsewu karst. The calculation of the flux is presented in Tab. 7.

et al. 2009; Singh \& Lal 2005), where organic fertilizer practices in Gunungsewu karst account for up to $40 \%$ of the carbon input of the soil. Organic fertilizer is the common practice in Gunungsewu karst, since local farmers raise livestock for additional income (Tanner et al. 2001). Local farmers usually have two to four goats or cows. They pile the manure until it is decomposed and put into the soils afterwards, during land preparation at the end of the dry season.
Organic carbon input, from a topo-sequence point of view, tends to be in the order of crest $>$ slope $>$ bottom of cockpits. The higher input of organic carbon in the crest of conical karst hills is a result from the higher input of mixed perennial crops litter. Litter of perennial crops is left on the land and continues over a considerably long period. On the contrary, organic carbon input from litter is very low in the bottom of cockpit where the major land use is seasonal crops. Leaves of seasonal

Tab. 7: Calculation of Carbon flux.

\begin{tabular}{|c|c|c|c|c|c|c|c|}
\hline \multirow{2}{*}{ No } & \multirow{2}{*}{ Position } & \multicolumn{2}{|c|}{ Organic C Input } & \multicolumn{2}{|c|}{ Respiration } & \multicolumn{2}{|c|}{ C Sink } \\
\hline & & Tons/ha/y & $\%$ & Tons/ha/y & $\%$ & Tons/ha/y & $\%$ \\
\hline 1 & Crest & 22.41 & 39.42 & 4.56 & 8.02 & 17.85 & 31.40 \\
\hline 2 & Slope & 18.08 & 31.80 & 3.29 & 5.79 & 14.79 & 26.02 \\
\hline \multirow[t]{3}{*}{3} & Foot & 16.36 & 28.78 & 1.75 & 3.08 & 14.61 & 25.70 \\
\hline & Average & 18.95 & 33.33 & 3.20 & 5.63 & 15.75 & 27.70 \\
\hline & Total Organic C Input & 56.85 & & & & & \\
\hline
\end{tabular}

\begin{tabular}{|c|c|c|c|c|c|}
\hline & \multirow{2}{*}{ Total Carbon Sink } & \multicolumn{3}{|c|}{ Redistributed } & \multirow{2}{*}{$\begin{array}{c}\text { Remain in the } \\
\text { Soil (SOC) }\end{array}$} \\
\hline & & Erosion & $D O C$ & $D I C$ & \\
\hline Tons/ha/year & 15.75 & 0.015 & 0.67 & 0.56 & 14.50 \\
\hline$\%$ from Carbon Sink & 100.00 & 0.10 & 4.25 & 3.56 & 92.10 \\
\hline$\%$ from Total Carbon & 83.59 & 0.08 & 3.54 & 2.96 & 76.54 \\
\hline
\end{tabular}


crops are not returned to the land. Instead, it is usually brought out of the land for cattle feeding. The input carbon in the bottom of the cockpit is mostly from the plant residue, i.e. from roots and the bottom part of seasonal crops. Therefore, input from litter in the bottom of the cockpit can be omitted.

Carbon input from those three organic matters is then decomposed by microorganisms and converted to inorganic carbon in the form of soil $\mathrm{CO}_{2}$. Soil $\mathrm{CO}_{2}$ in the Gunungsewu karst is highly variable depending on season and agricultural practices. The higher $\mathrm{CO}_{2}$ soil occurs in the seasonal crop during the rainy/wet season. This pattern echoes the general pattern from different areas, as suggested by White (2013), of which soil $\mathrm{CO}_{2}$ is higher in the growing period. Carbon dioxide productivity of roots and soil bacteria increases with temperature and water availability (Ford \& Williams 2007). The higher $\mathrm{CO}_{2}$ in the rainy season is likely favored by good soil drainage in the area as well, which means aerobic decomposition can take place optimally. The result, however, shows that seasonal variation of SOC in dry land cultivation is fluctuated more compared to that in mixed perennial cropland. Higher variability of SOC in cultivation land is favored by plant rotation between different plant commodities and left bare in the dry season. This rotation in turn governs the temporal variability of organic input to the soils and SOC. Since the seasonal cropland is ploughed intensively, higher soil $\mathrm{CO}_{2}$ also seems governed by better soil aeration. Maximum soil $\mathrm{CO}_{2}$ encounter in the area is $17,000 \mathrm{ppm}$ with an average of 4,307 ppm $(\mathrm{n}=27)$. This magnitude is 13 degrees higher than that of the atmosphere level, which is measured at $344 \mathrm{ppm}$.

Soil $\mathrm{CO}_{2}$ at the low depth is further emitted to the atmosphere through soil respiration. The rest of the carbon is stored in karst soils and transported to the deeper zone and to the ocean through the water cycle. The result shows that respiration in Gunungsewu karst is less than one fourth of the total organic carbon input. Most of the organic carbon input is stored in the form of SOC and soil $\mathrm{CO}_{2}$ as carbon sink. A small portion of the carbon sink is redistributed through the water cycle to the lower and deeper karst zone. In the surface, SOC is redistributed by erosion from the crest to the lower slope. However, redistributed SOC by erosion in Gunungsewu karst is very small compared to the total carbon sink, which amounted to only 0.025 tons/ha/y or approximately $0.08 \%$. Therefore, redistribution of SOC can be omitted.
Some other portions of carbon are redistributed to deeper zones by percolating water, in the form of dissolved and particulate organic carbon (DOC), as well as dissolved inorganic carbon (DIC). Organic carbon transported by percolating water in the Gunungsewu karst is $0.43 \%$ from that of total carbon sink. Organic carbon in Gunungsewu karst water (underground river and drip water) is in the similar range of organic carbon reported from Postojna and Virginia (Simon et al. 2007). Meanwhile, the percentage of inorganic carbon from percolated water is $3.6 \%$; this number is excluded $\mathrm{CO}_{2}$ degassing from calcite precipitation in the cave during speleothems' formation. $\mathrm{CO}_{2}$ degassing - as suggested by previous works (Madonia et al. 2012; Milanolo \& Gabrovšek 2015) - must have taken place in the area, since densely packed speleothems are found in some passages of the Gilap Cave.

DIC in the Gunungsewu karst in the form of $\mathrm{HCO}_{3}^{-}$ is in the range generally found in different places from Southern China (Jiang 2013; Liu et al. 2007) to Southern Japan (Yamanaka 2012). However, the results show that the two study sites exhibit different temporal variability. A conduit system with a complex aquifer, as represented by the Gilap subterranean river, has higher temporal variability than that in the epikarst spring of Ngeleng. Such high variability in the subterranean river should be explained by high variability of discharge with the different flow regime. This result echoes the finding from Southwest China: Zeng et al. (2016) suggested that the variation of discharge is the major control of DIC. A much lower DIC of the Gilap underground river in the rainy season must be a result of allogenic recharge through sinking stream and autogenic point recharge from ponors.

With respect to carbon flux, the results unveil that carbon sink in the karst area is much higher than those suggested in previous works (Huang et al. 2015; Liu \& Zhao 2000; Liu et al. 2010; White 2013; Yuan 1997). Carbon sink estimated from DIC and DOC account for less than ten percent of the total carbon sink in the karst area or only five percent as of total carbon, which is cycling in the karst area. Ninety percent of carbon sink, or $75 \%$ of the total cycling carbon in the karst area, is stored in the soils as SOC. Thereafter, considering the carbon input from biomass and organic fertilizer, the magnitude of carbon sink in the karst area should be much higher in the order of nine than that estimated previously from DIC. 


\section{CONCLUSION}

In summary, the nature of carbon flux in Gunungsewu karst is subject to temporal and spatial variability. Temporal variability of carbon flux is governed by variability of agricultural practices during dry and wet seasons. Input of carbon to the karst area is higher in the wet season when agricultural crop and natural vegetation are more abundant. Seasonal variability is not only in terms of carbon input, but also with regard to $\mathrm{SOC}$ and soil $\mathrm{CO}_{2}$. Higher SOC and $\mathrm{CO}_{2}$ take place in the wet season. Since topographic position dictates agricultural land uses, carbon flux in Gunungsewu karst is subject to topographical position within conical hill topo-sequence. The major input of carbon to the Gunungsewu karst is from biomass and organic fertilizer. Organic carbon input, from a toposequence point of view, tends to be in the order of crest
$>$ slope $>$ bottom of cockpits. Carbon is stored mostly in the soil as SOC. Approximately $20 \%$ of SOC is emitted to the atmosphere through soil respiration. Six percent of carbon is transported to the deeper zone through a hydrological cycle in the form of DIC and DOC or particulate organic carbon. Considering SOC, the importance of karst area as carbon sink is much bigger than previously estimated, solely from DIC. Therefore, comprehensive accounting of carbon sink in the karst area must consider SOC as carbon storage. Further attempts should be made to include above ground carbon storage in the form of biomass and inorganic carbon input from atmosphere to gain a better understanding of carbon sink potential in the karst area.

\section{ACKNOWLEDGMENT}

This research was funded by the Higher Education Directorate of Indonesian Government 2012-2014. Thanks due to Prof. Dr. Zhang Cheng (International Research
Centre on Karst, Gulin-China) and Prof. Dr. Yogjun Jiang (Dept. of Geography, Southwest Univ. China) for the constructive comments.

\section{REFERENCES}

Adji, T.N., 2012: Wet season hydrochemistry of Bribin Cave in Gunung Sewu Karst, Indonesia.- Environmental Earth Sciences, 67, 6, 1563-1572. http:// dx.doi.org/10.1007/s12665-012-1599-x

Adji, T.N., Haryono, E., Fatchurohman, H. \& R. Oktama, 2016: Diffuse flow characteristics and their relation to hydrochemistry conditions in the Petoyan Spring, Gunungsewu Karst, Java, Indonesia.- Geosciences Journal, 20, 3, 381-390. http://dx.doi.org/10.1007/ s12303-015-0048-8

Adji, T.N. \& I.Y. Bahtiar, 2016: Rainfall-discharge relationship and karst flow components analysis for karst aquifer characterization in Petoyan Spring, Java, Indonesia.- Environmental Earth Sciences, 75, 9, 735. http://dx.doi.org/10.1007/s12665-016$5553-1$

Balazs, D., 1968: Karst Regions in Indonesia.- Karszt-es Barlangkutatas Vol. 5, Globus nyomda, pp. 61, Budapest.

Bemmelen, R.W. van, 1970: The Geology of Indonesia. $2^{\text {nd }}$ ed.- Martinus Nijhoff, pp. 732, The Hague.
Berner, R.A., Lasaga, A. \& R. Garrels, 1983: The carbonate-silicate geochemical cycle and its effect on amospheric carbon dioxide over the pas 100 million years.- American Journal of Science, 283, 7, 641-683. http://dx.doi.org/10.2475/ajs.283.7.641

Eiche, E., Hochschild, M., Haryono, E. \& T. Neumann, 2016: Characterization of Recharge and Flow Behaviour of Different Water Sources in Gunung Kidul and Its Impact on Water Quality Based on Hydrochemical and Physico-Chemical Monitoring.- Applied Water Science. http://dx.doi.org/10.1007/ s13201-016-0426-Z

Ford, D.C. \& P.W. Williams, 2007: Karst Hydrogeology and Geomorphology.- John Wiley \& Sons Ltd, pp. 562, Chicester.

Haryono, E., 2000: Some properties of Epikarst Drainage System in Gunung Kidul Regency, Yogyakarta, Indonesia.- The Indonesian Journal of Geography, $32,10-15$. 
Haryono, E. \& M.J. Day, 2004: Landform differentiation within the Gunung Kidul Karst, Java-Indonesia.Journal of Cave and Karst Studies, 66, 2, 62-68.

Haryono, E., 2011: Introduction to Gunungsewu karst: Field Guide, Asian Trans-Diciplinary Karst Conference 2011.- Karst Reseach Group, Fac.of Geography, UGM.

Haryono, E., 2013: Uplift Evidence from Karst Morphology, Preliminary Evidence from Blambangan Peninsula Karst.- In: M. Filippi \& P. Bosák (eds.) Proceedings of the 16th International Congress of Speleology, $21^{\text {st }}-28^{\text {th }}$ July 2013, Brno, Czech Republic. Czech Speleological Society, 3, 90-93, Praha.

Huang, F., Zhang, C., Xie, Y., Li, L. \& J. Cao, 2015: Inorganic carbon flux and its source in the karst catchment of Maocun, Guilin, China.- Environmental Earth Sciences, 74, 2, 1079-1089. http://dx.doi. org/10.1007/s12665-015-4478-4

Jiang, Y., 2013: The contribution of human activities to dissolved inorganic carbon fluxes in a karst underground river system: Evidence from major elements and $\delta^{13} \mathrm{C}_{\mathrm{DIC}}$ in Nandong, Southwest China.- Journal of Contaminant Hydrology, 152, 1-11. http:// dx.doi.org/10.1016/j.jconhyd.2013.05.010

Jiang, Y., Hu, Y. \& M. Schirmer, 2013: Biogeochemical controls on daily cycling of hydrochemistry and $\delta^{13} \mathrm{C}$ of dissolved inorganic carbon in a karst springfed pool.- Journal of Hydrology, 478, 157-168. http://dx.doi.org/10.1016/j.jhydrol.2012.12.001

Liu, Z., Dreybrodt, W. \& H. Wang, 2010: A new direction in effective accounting for the atmospheric $\mathrm{CO}_{2}$ budget: Considering the combined action of carbonate dissolution, the global water cycle and photosynthetic uptake of DIC by aquatic organisms.Earth-Science Reviews, 99, 3-4, 162-172. http:// dx.doi.org/10.1016/j.earscirev.2010.03.001

Liu, Z., Li, Q., Sun, H. \& J. Wang, 2007: Seasonal, diurnal and storm-scale hydrochemical variations of typical epikarst springs in subtropical karst areas of SW China: Soil $\mathrm{CO}_{2}$ and dilution effects.- Journal of Hydrology, 337, 1-2, 207-223. http://dx.doi. org/10.1016/j.jhydrol.2007.01.034

Liu, Z. \& J. Zhao, 2000: Contribution of carbonate rock weathering to the atmospheric $\mathrm{CO}_{2}$ sink.- Environmental Geology, 39, 9, 1053-1058. http://dx.doi. org/10.1007/s002549900072

Mackenzie, F. T., Lerman, A. \& A.J. Andersson, 2004: Past and present of sediment and carbon biogeochemical cycling models.- Biogeosciences Discussions, 1, 1, 11-32. http://dx.doi.org/10.5194/bg-1-11-2004
Madonia, P., Bellanca, A., Di Pietro, R. \& L. Mirabello, 2012: The role of near-surface cavities in the carbon dioxide cycle of karst areas: Evidence from the Carburangeli Cave Natural Reserve (Italy).- Environmental Earth Sciences, 67, 8, 2423-2439. http:// dx.doi.org/10.1007/s12665-012-1693-0

Milanolo, S. \& F. Gabrovšek, 2015: Estimation of carbon dioxide flux degassing from percolating waters in a karst cave: Case study from Bijambare cave, Bosnia and Herzegovina.- Chemie Der Erde - Geochemistry, 75, 4, 465-474. http://dx.doi.org/10.1016/j. chemer.2015.10.004

de Montety, V., Martin, J.B., Cohen, M.J., Foster, C. \& M.J. Kurz, 2011: Influence of diel biogeochemical cycles on carbonate equilibrium in a karst river.Chemical Geology, 283, 1, 31-43. http:/dx.doi. org/10.1016/j.chemgeo.2010.12.025

Mulatsih, S., Haryono, E. \& Sutikno, 2011: Carbon Flux in Soil Along Karst Hillslope Toposequence Above Wonosari Formation at Gunungkidul District.- In E. Haryono, T. N. Adji, \& Suratman (eds.) Asian Trans-Diciplinary Karst Conference 2011, Yogyakarta, Indonesia. Faculty of Geography, UGM, 219227, Yogyakarta.

Rahadjo, W., Rumidi, S. \& H.M.D. Rosidi, 1995: Peta Geologi Lembar Yogyakarta, Jawa. 1:100.000.- P3G, Bandung.

Shrestha, B.M., Williams, S., Easter, M., Paustian, K. \& B.R. Singh, 2009: Modeling soil organic carbon stocks and changes in a Nepalese watershed.- Agriculture, Ecosystems and Environment, 132, 1-2, 91-97. http://dx.doi.org/10.1016/j.agee.2009.03.003

Simon, K.S., Pipan, T. \& D.C. Culver, 2007: A conceptual model of the flow and distribution of organic carbon in caves.- Journal Of Cave And Karst Studies, 69, 2, 279-284

Singh, B.R. \& R. Lal, 2005: The potential of soil carbon sequestration through improved management practices in Norway.- Environment, Development and Sustainability, 7, 1, 161-184. http://dx.doi. org/10.1007/s10668-003-6372-6

Surono, Toha, B. \& J. Sudarno, 1992: Peta Geologi Lembar Surakarta-Giritontro, Jawa. 1:100.000.- P3G, Bandung.

Suyoto, 2005: Stratigrafi sikuen cekungan depan busur Neogen Jawa selatan berdasarkan data di daerah Pegunungan Selatan, Yogyakarta.- Institut Teknologi Bandung Disertation, Bandung. 
Tanner, J.C., Holden, S.J., Owen, E., Winugroho, M. \& M. Gill, 2001: Livestock sustaining intensive smallholder crop production through traditional feeding practices for generating high quality manure-compost in upland Java.- Agriculture, Ecosystems \& Environment, 84, 1, 21-30. http://dx.doi.org/10.1016/ s0167-8809(00)00177-8

Walkley, A., \& I.A. Black, 1934: An examination of the Degtjareff method for determining soil organic matter and a proposed modification of the chromic acid titration method.- Soil Science, 37, 1, 29-38. http://dx.doi.org/10.1097/00010694-19340100000003

Waltham, A.C., Smart, P.L., Friederich, H., Eavis, A.J. $\&$ T. Atkinson, 1983: The caves of Gunung Sewu, Java.- Cave Science, 10, 2, 55-96.

White, W.B., 2013: Carbon fluxes in Karst aquifers: Sources, sinks, and the effect of storm flow.- Acta Carsologica, 42, 2-3, 177-186. http://dx.doi. org/10.3986/ac.v42i2-3.659
Yamanaka, M., 2012: Contributions of C3/C4 organic materials and carbonate rock to dissolved inorganic carbon in a karst groundwater system on Miyakojima Island, southwestern Japan.- Journal of Hydrology, 412-413, 151-169. http://dx.doi.org/10.1016/j. jhydrol.2011.07.046

Yuan, D., 1997: The carbon cycle in karst.- Zeitschrift Fur Geomorphologie, 108, 91-102.

Yuan, D. \& C. Zang, 2002: Karst processes and the carbon cycle: Final Report of IGCP379.- Geological Publishing House, pp. 220, Beijing.

Zeng, C., Liu, Z., Zhao, M. \& R. Yang, 2016: Hydrologically-driven variations in the karst-related carbon sink fluxes: Insights from high-resolution monitoring of three karst catchments in Southwest China.Journal of Hydrology, 533, 74-90. http://dx.doi. org/10.1016/j.jhydrol.2015.11.049 